\title{
Aged boreal biomass-burning aerosol size distributions from BORTAS 2011
}

\author{
K. M. Sakamoto ${ }^{1,2}$, J. D. Allan ${ }^{3}$, H. Coe ${ }^{3}$, J. W. Taylor ${ }^{3}$, T. J. Duck ${ }^{2}$, and J. R. Pierce ${ }^{1,2}$ \\ ${ }^{1}$ Department of Atmospheric Science, Colorado State University, Fort Collins, CO, USA \\ ${ }^{2}$ Department of Physics and Atmospheric Science, Dalhousie University, Halifax, NS, Canada \\ ${ }^{3}$ School of Earth, Atmospheric \& Environmental Sciences, University of Manchester, Manchester, UK
}

Correspondence to: J. R. Pierce (jeffrey.pierce@ colostate.edu)

Received: 6 September 2014 - Published in Atmos. Chem. Phys. Discuss.: 19 September 2014

Revised: 22 January 2015 - Accepted: 23 January 2015 - Published: 16 February 2015

\begin{abstract}
Biomass-burning aerosols contribute to aerosol radiative forcing on the climate system. The magnitude of this effect is partially determined by aerosol size distributions, which are functions of source fire characteristics (e.g. fuel type, MCE) and in-plume microphysical processing. The uncertainties in biomass-burning emission number-size distributions in climate model inventories lead to uncertainties in the $\mathrm{CCN}$ (cloud condensation nuclei) concentrations and forcing estimates derived from these models.

The BORTAS-B (Quantifying the impact of BOReal forest fires on Tropospheric oxidants over the Atlantic using Aircraft and Satellite) measurement campaign was designed to sample boreal biomass-burning outflow over eastern Canada in the summer of 2011. Using these BORTASB data, we implement plume criteria to isolate the characteristic size distribution of aged biomass-burning emissions (aged $\sim 1-2$ days) from boreal wildfires in northwestern Ontario. The composite median size distribution yields a single dominant accumulation mode with $D_{\mathrm{pm}}=230 \mathrm{~nm}$ (numbermedian diameter) and $\sigma=1.5$, which are comparable to literature values of other aged plumes of a similar type. The organic aerosol enhancement ratios $(\triangle \mathrm{OA} / \triangle \mathrm{CO})$ along the path of Flight b622 show values of $0.09-0.17 \mu \mathrm{g} \mathrm{m}^{-3} \mathrm{ppbv}^{-1}$ (parts per billion by volume) with no significant trend with distance from the source. This lack of enhancement ratio increase/decrease with distance suggests no detectable net OA (organic aerosol) production/evaporation within the aged plume over the sampling period (plume age: 1-2 days), though it does not preclude OA production/loss at earlier stages.
\end{abstract}

A Lagrangian microphysical model was used to determine an estimate of the freshly emitted size distribution corresponding to the BORTAS-B aged size distributions. The model was restricted to coagulation and dilution processes based on the insignificant net OA production/evaporation derived from the $\triangle \mathrm{OA} / \triangle \mathrm{CO}$ enhancement ratios. We estimate that the young-plume median diameter was in the range of $59-94 \mathrm{~nm}$ with modal widths in the range of 1.7-2.8 (the ranges are due to uncertainty in the entrainment rate). Thus, the size of the freshly emitted particles is relatively unconstrained due to the uncertainties in the plume dilution rates.

\section{Introduction}

\section{Biomass-burning particles}

Biomass burning is a significant emission source of carbonaceous aerosols to the global atmosphere (Andreae and Merlet, 2001; Reid et al., 2005). In addition to releasing high levels of greenhouse gases $\left(\mathrm{CO}_{2}, \mathrm{CO}\right)$ and volatile organic compounds, biomass burning releases smoke particles that have climate impacts through the direct and indirect aerosol effects. These particles are primarily composed of a mixture of black carbon (BC) and organic carbon (OC), with inorganics contributing some mass (Capes et al., 2008; Carrico et al., 2010; Cubison et al., 2011; Hecobian et al., 2011; Hennigan et al., 2011; Hudson et al., 2004; Reid et al., 2005). These particles directly affect Earth's radiation balance and climate by scattering and absorbing incoming solar radiation (Haywood, 2000; Jacobson, 2001). Biomass-burning (BB) parti- 
cles may also act as cloud condensation nuclei $(\mathrm{CCN})$ and affect climate and radiation through modifying cloud albedo and lifetime (Pierce et al., 2007; Spracklen et al., 2011) (indirect aerosol effects). Globally, the direct and indirect climate effects represent the largest uncertainties in radiative forcing as quantified by the recent IPCC report (Myhre et al., 2013), and biomass-burning emissions represent significant contributions to each of the effects globally (Alonso-Blanco, 2014; Lee et al., 2013).

The size of biomass-burning particles (and all particles in general) can have large impacts on the magnitude of these direct and indirect effects (Lee et al., 2013; Seinfeld and Pandis, 2006; Spracklen et al., 2011). Regarding the direct effect, the mass-scattering and mass-absorption efficiencies (the amount of scattering and absorption per mass of aerosol particles) depend on the size of the particles, so errors in the predicted/assumed values of biomass-burning particle size may lead to errors in simulated direct aerosol climate effects (Seinfeld and Pandis, 2006). Regarding the indirect effect, particles that are larger in diameter and more hygroscopic are more likely to act as CCN (Petters and Kreidenweis, 2007). Typically, particles larger than $30-100 \mathrm{~nm}$ act as $\mathrm{CCN}$ depending on conditions and hygroscopicity (Petters and Kreidenweis, 2007; Petters et al., 2009), though this range may be slightly larger or smaller for fresh biomassburning particles due to these particles being initially more hydrophobic/hydrophilic (depending on fuel type) than typical ambient aerosol (Carrico et al., 2010; Engelhart et al., 2012; Petters and Kreidenweis, 2007). Furthermore, for constant emissions mass, a factor-of-2 change in diameter leads to a factor-of- 8 change in number emissions, which may contribute to significant changes in CCN concentrations (Pierce et al., 2007; Spracklen et al., 2011). Thus, it is important to provide accurate emissions sizes from biomass-burning sources to atmospheric aerosol models looking at aerosolclimate interactions. Lee et al. (2013) found that uncertainties in biomass-burning aerosol emission diameters were responsible for large uncertainties in $\mathrm{CCN}$ concentrations in the GLOMAP model (third largest CCN sensitivity out of 28 globally).

Atmospheric processing causes the physical and chemical properties of BB aerosol evolve over time. These processes have an effect on the size and composition of the particles, and thus influence their direct and indirect effects. Coagulation is a driving factor in size-distribution evolution due to the high concentrations of particles within plumes (Andreae and Merlet, 2001; Capes et al., 2008). Production of secondary organic aerosol (SOA) in-plume has been observed in chamber studies (Cubison et al., 2011; Grieshop et al., 2009; Hennigan et al., 2011; Heringa et al., 2011; Ortega et al., 2013) and in the field (DeCarlo et al., 2010; Lee et al., 2008; Reid et al., 1998; Yokelson et al., 2009), and this SOA will condense onto the particles, increasing their size. In addition, the primary organic aerosol (POA) emitted by the fires may evaporate during the dilution of the plume (Huffman et al.,
2009; May et al., 2013). Finally, new particle formation in smoke plumes has been observed in smog chamber studies (Hennigan et al., 2012) as well as in the field (Andreae et al., 2001; Hobbs et al., 2003; Rissler et al., 2006).

In global and regional modelling of biomass-burning aerosols, mass-based biomass-burning inventories are the standard and are generally not accompanied by size data (Reid et al., 2009; van der Werf et al., 2010; Wiedinmyer et al., 2011), leaving size-distribution estimates to the individual investigator. Current global and regional atmospheric aerosol models have grid box spatial scales (tens of hundreds of kilometres) much larger than many initial biomassburning plume widths $(<10 \mathrm{~km})$. This means that sub-grid aging of aerosol plumes by microphysical processes (coagulation, condensation/evaporation and nucleation) will lead to changes in the size distribution that the models cannot explicitly resolve. Therefore, the biomass-burning emissions size distributions must be aged distributions that already account for sub-grid processes. Quantifying the natural variations in biomass-burning aerosols is therefore necessary for accurate predictions. Previous studies of field and lab experiments show biomass-burning size distributions vary according to plume age, combustion phase, and fuel type (Adler et al., 2011; Capes et al., 2008; Hobbs et al., 2003; Hosseini et al., 2010; Janhäll et al., 2010; Okoshi et al., 2014). A review of observed size-distribution data by Janhäll et al. (2010) shows the differences in modal width and median diameter as a function of fuel type (forest, savannah, grass), modified combustion efficiency, and plume age (fresh versus aged). Combustion chamber experiments in the FLAME lab have demonstrated similar fuel-type differences in fresh BB size distributions (Levin et al., 2010).

Due to the combination of emission and atmospheric processing factors contributing to the evolution of the $\mathrm{BB}$ aerosol size distribution, characterization of observed, aged $\mathrm{BB}$ aerosol is valuable. Adding to the database of observations helps constrain the uncertainties associated with aerosol size. Thus, to improve BB-aerosol-climate interactions in models, there is a need to characterize the size of particles in aging and aged biomass-burning plumes for a range of fire types and atmospheric conditions (Bauer et al., 2010; Chen et al., 2010; Lee et al., 2013; Pierce et al., 2007; Reddington et al., 2011; Spracklen et al., 2011). In this paper, we specifically investigate the size distributions measured in aged plumes (1-2 days) of large boreal forest fires over Canada.

In this paper, we analyse size-distribution and organic aerosol data from BORTAS-B flights that sampled highly concentrated smoke plumes over eastern Canada on 20-21 July 2011. A brief overview of the BORTAS-B campaign, instrumentation, and source fire conditions are provided in Sects. 2.1 and 2.2. A description of the quantitative plume criteria used to determine plume (vs. out of plume) sampling periods is found in Sect. 2.3. In addition to observational data, we use an aerosol-microphysics box model to sim- 
ulate the microphysical evolution of number-size distributions. This model was employed to estimate the likely youngplume size distribution associated with the source fires sampled by BORTAS-B. A full model description is provided in Sect. 2.4. We present the BORTAS-B research flight results in Sect. 3, which include the measured aged size distributions, evidence for/against net OA (organic aerosol) production, and the aging simulations. Finally, we provide conclusions in Sect. 4.

\section{Methods}

\subsection{BORTAS overview}

The BORTAS-B (Quantifying the impact of BOReal forest fires on the Tropospheric oxidants over the Atlantic using Aircraft and Satellites) measurement campaign was held in eastern/Atlantic Canada from 11 July to 3 August 2011 (Palmer, 2013). The goal was to characterize pyrogenic outflow from boreal forest wildfires using a variety of sampling and observational techniques with emphasis on plume photochemical evolution.

BORTAS-B incorporated predictive chemical transport modelling (GEOS-Chem), satellite observations, a groundbased in situ network of sondes (Environment Canada) and ground-base samplers and profilers (Dalhousie Ground Station, DGS), and the UK Facility for Airborne Atmospheric Measurements Airborne Research Aircraft (FAAMARA) for in-flight sampling. For a complete overview of the BORTAS-B set-up and instrumentation see Palmer (2013). The ARA flew 14 research flights over the campaign period.

The flight paths of the ARA flights that we analyse in this paper can be seen in Fig. 1. Flights BAe-b622 and BAeb623 were research flights between Halifax, NS, and Sherbrooke, QC, spanning 20-21 July 2011. They flew ascent and descent patterns (ranging $\sim 1-7 \mathrm{~km}$ a.s.l.) to sample vertical and horizontal transects in regions forecasted to contain biomass-burning plumes. These flights were selected because they were roughly co-located and back to back, increasing the likelihood of sampling similar outflow and allowing for a common plume criteria to be applied across both flights. They also contained the majority of the biomassburning aerosol sampled during the 14-flight campaign.

In addition, Flight b622 sampled along a relatively straight path to/from the fires that allowed for analysis of the evolution of plume aerosol properties (Flight b623 had a much more complicated and compact sampling path so we did not use this flight to determine the evolution of aerosol properties). We have divided these flights into vertical transects by ascent/descent with the midpoints transect represented in Fig. 1.

The sampled wildfire plumes originated from intense regional fires near the northwestern Ontario-Manitoba border (centred at $52^{\circ} \mathrm{N}, 93^{\circ} \mathrm{W}$ ). The MODIS hotspots in

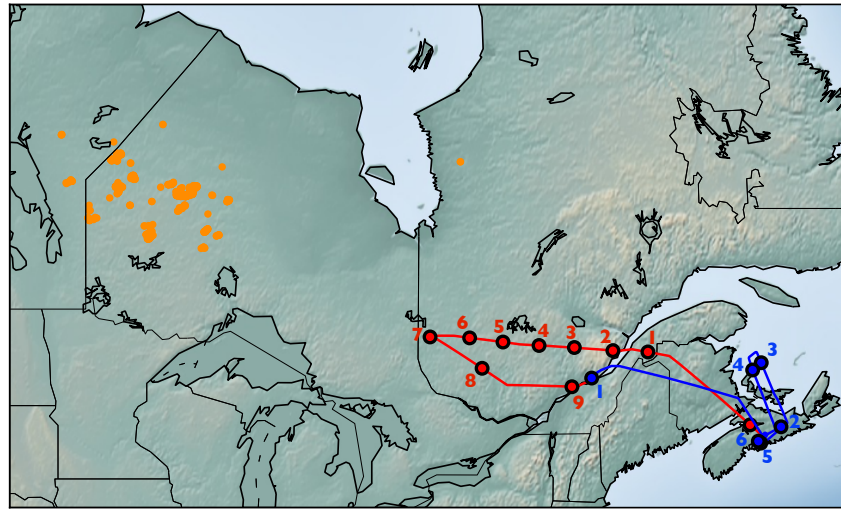

Figure 1. BORTAS-B ARA research Flight b622 (red) from Nova Scotia to Quebec and the return Flight b623 (blue), both on 2021 July 2011. Circles represent midpoints of ascent/descent transects along the flight paths. The ARA flew through biomass-burning emissions originating from fires in northwestern Ontario. The 1720 July 2011 MODIS hotspot fires (fire radiative power > 100 MW) are plotted in orange.

Fig. 1 show a number of intense fires (fire radiative power $>100 \mathrm{MW}$ ) in northwestern Ontario for the 3 days prior to the analysed flights (17-20 June 2011). According to the Ontario Ministry of Natural Resources, Ontario experienced one of its worst fire seasons in terms of burned area with 635, 374 ha burned in 2011. The abundance of individual fires in a relatively large source region led to mixed combustion phases and dominant hotspots over the course of the campaign. A combination of flaming and smouldering phases were reported by Natural Resources Canada with primary fuels consisting of jack pine (Pinus banksiana) and black spruce (Picea mariana) throughout the fire region (Ontario ministry of natural resources: 2011 forest summary).

The dominant west-east climatological meteorology during the BORTAS-B campaign allowed the biomass-burning emissions from these fires to be transported downwind over the ground base (DGS) in Halifax, NS, $\left(44.5^{\circ} \mathrm{N}, 63.1^{\circ} \mathrm{W}\right)$. The plumes intersected by flights b622 and b623 had a physical transport age estimated through HYSPLIT back trajectories of between 1-2 days as summarized in Table 1 . The back-trajectory analysis (not shown) shows air masses passing over the biomass-burning region later being intersected by the flight paths at varying altitudes. The estimated photochemical age of the plumes, calculated by Palmer et al. (2013) (by non-methane hydrocarbon analysis; Parrish et al., 2007), were 1-5 days for Flight b622 and 2-4 days for Flight b623. These estimates may be longer than the physical transport ages due to the entrainment of background air (which is more photochemically aged) into the plumes. 
Table 1. Approximate physical transport age and distance of numbered flight transect midpoints from source fires. Ages were estimated by HYSPLIT back trajectories. The large ranges in the determined values are due to the large extent of the source fire region and variability in fire conditions. The distances are given from transect midpoints to the source fire region $( \pm 150 \mathrm{~km})$.

\begin{tabular}{lrr}
\hline Transect \# & $\begin{array}{r}\text { Approx. } \\
\text { physical age (h) }\end{array}$ & $\begin{array}{r}\text { Approx. distance } \\
\text { from source (km) }\end{array}$ \\
\hline \multicolumn{3}{c}{ Flight b622 } \\
\hline 1 & $27-32$ & $1450-1750$ \\
2 & $27-32$ & $1350-1650$ \\
3 & $27-32$ & $1250-1550$ \\
5 & $27-32$ & $1150-1450$ \\
6 & $18-25$ & $1050-1350$ \\
7 & $18-25$ & $850-1150$ \\
8 & $18-25$ & $850-1150$ \\
9 & $18-25$ & $1050-1350$ \\
& $24-30$ & $1350-1650$ \\
\hline 1 & Flight b623 \\
2 & $24-36$ & $1350-1650$ \\
$3-4$ & $28-36$ & $2050-2350$ \\
$5-6$ & $28-36$ & $1850-2150$ \\
\hline
\end{tabular}

\subsection{ARA instrumentation}

The ARA aircraft was outfitted with instruments designed for sampling chemical and physical characteristics of biomassburning outflow. Gaseous and particulate in-flight sampling was accomplished across a suite of instruments; the relevant instruments for this study are described below. A full description of all payload instruments can be found in Palmer (2013).

The suite of instruments on the ARA included measurements of multiple gaseous biomass-burning tracers. Carbon monoxide (CO) mole fraction was measured via a VUV (vacuum ultraviolet) fast fluorescence $\mathrm{CO}$ analyser averaged over $1 \mathrm{~s}$ ( $3 \%$ estimated accuracy). Acetonitrile $\left(\mathrm{CH}_{3} \mathrm{CN}\right)$, a biomass-burning marker VOC (volatile organic compound) associated with plant pyrolysis, was measured along with a number of other VOCs with a proton-transfer-reaction mass spectrometer (PTR-MS) system (University of East Anglia). The PTR-MS concentrations were averaged over $1 \mathrm{~s}$ with an estimated precision of $\pm 37 \mathrm{ppt}$ (parts per trillion; Palmer, 2013).

Aerosol composition measurements used here were taken by (i) refractory $\mathrm{BC}$ mass and number measurements from a single particle soot Photometer (SP2) (accuracy $20 \%$, precision $5 \%, 5 \mathrm{~s}$ averaging time) and (ii) non-refractory OA via an aerosol mass spectrometer (precision $\sim 15-150 \mathrm{ng} \mathrm{m}^{-3}$ ) both operated by the University of Manchester (Jolleys et al., 2014; Taylor et al., 2014). The number concentrations of the combined aerosol particles was measured by scanning mobility particle sizer (SMPS) with 26 lognormally spaced diameter bins ranging from 20 to $330 \mathrm{~nm}$ and corrected to STP (standard temperature and pressure). A full scan takes $60 \mathrm{~s}$ (Palmer, 2013). The SMPS data was inverted using the commonly used Wiedensohler (1988) parameterization, however recent work has suggested that this may be quantitatively unreliable for applications to aircraft data due to variations in the charging efficiency with pressure (López-Yglesias and Flagan, 2013; Leppä et al., 2014). While this may have affected the magnitude of the number concentrations, no altitude dependency was noted in the sizing data, so the conclusions of this paper regarding particle size are unaffected.

The combination of gas and particle tracer measurements listed above were used to identify flight periods of biomassburning plume sampling, determine if SOA formation or OA evaporation may have occurred in the plume, and characterize the size distribution of aerosols within the plume.

\subsection{Plume criteria}

We determine if measurements are in-plume versus out-ofplume using threshold plume criteria. We designate sampling periods as in-plume if pre-specified threshold values of four tracer species - $\mathrm{CO}, \mathrm{CH}_{3} \mathrm{CN}, \mathrm{BC}$, and $\mathrm{OA}$ - were exceeded. For out-of-plume conditions, we determine "background values" for each tracer by averaging the tracers over the out-ofplume periods.

Carbon monoxide ( $\tau_{\mathrm{co}} \sim$ months; Staudt et al., 2001$)$ and acetonitrile ( $\tau_{\text {ace }} \sim 6$ months; Holzinger et al., 2005 ) were used in conjunction as gaseous tracers due to their high mixing ratios in biomass-burning plumes relative to the background and long atmospheric lifetimes relative to the estimated plume transport times. The background $\mathrm{CO}$ levels were $80-120 \mathrm{ppbv}$ (parts per billion by volume) with an overall average of $100 \mathrm{ppbv}$. The threshold $\mathrm{CO}$ value was set to $150 \mathrm{ppbv}(1.5 \times$ [background] $)$, with some $\mathrm{CO}$ concentrations in-plume reaching 10 times background concentrations (1000 ppbv). The threshold $\mathrm{CH}_{3} \mathrm{CN}$ level was $200 \mathrm{pptv}$ (background $\sim 100 \mathrm{pptv}$ ).

The particulate matter thresholds (BC number, OA mass) were introduced to ensure high-enough aerosol contributions to the plume to analyse size distributions. This ensured highgas, low-aerosol sampling periods were not included in the size-distribution analysis. At least one case of this situation in BORTAS-B has been attributed by Franklin et al. (2014) to aerosol rainout during transport. The mean background concentrations for both $\mathrm{BC}$ number and $\mathrm{OA}$ mass were minimal $\left(<20 \mathrm{~cm}^{-3}\right.$ and $2 \mu \mathrm{g} \mathrm{m}^{-3}$, respectively). The threshold values were set to $50 \mathrm{~cm}^{-3}$ for BC number and $20 \mu \mathrm{g} \mathrm{m}^{-3}$ for OA mass. These thresholds for particles are higher relative to background than $\mathrm{CO}$ and $\mathrm{CH}_{3} \mathrm{CN}$ because we wanted to exclude a higher-elevation plume that had undergone aerosol wet deposition (see Sect. 3.2). 
The selected $\mathrm{CO}, \mathrm{CH}_{3} \mathrm{CN}$, aerosol data, and flight altitude time series for Flight b622 is shown in Fig. 2. The flight is divided into transects (labelled 1-9 and coloured) as seen in the altitude plot (Fig. 2, bottom). We use these in-plume time periods to differentiate between in-plume and background aerosols throughout the paper.

\subsection{Model description}

We use a Lagrangian box model to simulate the evolution of the biomass-burning size distribution due to coagulation. The model has 55 logarithmically distributed size bins that correspond to the size bins of the SMPS on the ARA and extend to both larger and smaller diameters. The model includes coagulation and dilution as the only physical processes, with no chemistry or speciation of the aerosol (we show in Sect. 3.2 that we cannot see evidence of net OA condensation/evaporation in the plume over the sampling period). The model distributions are therefore limited by the lack of condensational growth known to occur in BB plumes during the first few hours of aging (e.g. Reid et al., 1998).

We use an inverse method to estimate the initial young $(\sim 1 \mathrm{~h})$ size distributions by successively running the model from initial conditions to BORTAS observations forward in time and changing the initial size distribution until the model most closely matches the observed aged size distribution. This method estimates the initial distribution assuming that coagulation was the only physical process affecting the inplume particles. The box model does not include any cloud interaction chemistry, which could have influenced the distribution considerably depending on meteorological conditions, notably through wet deposition and aqueous chemistry.

Each model forward simulation requires the young sizedistribution input as a single lognormal mode with parameters: median diameter $\left(D_{\mathrm{pm}}\right)$, modal width $(\sigma)$, and particle number $\left(\mathrm{N}_{0}\right)$. For coagulation, we use the Brownian coagulation kernel of Fuchs (1964). Dilution of the plume in transport was modelled using a simple e-folding volume mixing time, $\tau_{\text {dil }}$. This parameter controlled the entrainment at each time step between the in-plume and background aerosol. The rate of plume dilution may significantly affect the rate of coagulation throughout the simulation (the coagulation rate is proportional to $\mathrm{N}^{2}$ ). Different values of $\tau_{\text {dil }}$ were tested to account for a range of entrainment rates as the dilution rate in the plume is relatively unconstrained. We test $\tau_{\text {dil }}$ values of 24,36 and $48 \mathrm{~h}$. The $36 \mathrm{~h}$ dilution timescale was calculated as the mean timescale for dilution from Gaussian plume equations with an initial plume width of $10 \mathrm{~km}$ in a neutral stability environment (Klug, 1969) (note, however, that expansion occurs at faster timescales early in the plume aging, and this timescale slows with time). The range (24-48 h) accounts for atmospheric stability and plume width variations in the BORTAS source region. The model simulation time is $48 \mathrm{~h}$ based on the upper age limits shown in Table 1.
To determine the best estimate for initial conditions, we simulate a range of young-plume parameters: median diameter, $D_{\mathrm{pm}}$, modal width, $\sigma$, and number, $\mathrm{N}_{0}$. The input median diameter range was between 60 and $120 \mathrm{~nm}$ (increment $=1 \mathrm{~nm}$ ), with $\sigma$ ranging from 1.0 to 2.5 (increment $=0.1$ ) and $\mathrm{N}_{0}$ ranging from 5000 to $150000 \mathrm{~cm}^{-3}$ (increment $=500 \mathrm{~cm}^{-3}$ ). The parameter space was optimized by brute force (i.e. every combination of input parameters was simulations) for each set dilution time and the final modelled size distribution was compared to the observed in-plume size distribution by an equally weighted objective function. The objective function used was the sum of the absolute residual across the SMPS range. Modelled data outside of the SMPS size range was not used in the objective function.

\section{Results}

\subsection{Observed size distributions}

Observed SMPS size distributions for individual plume transects showed highly elevated particle counts with little variation between transects and flights. The transect-divided data for Flight b622 are shown in Fig. 3. Transects $2-6$ and 9 , show a clearly elevated accumulation mode within the plume, with peak median diameters of $180-240 \mathrm{~nm}$. Transects 1,7 and 8 have significantly less data $(<3$ data points per size bin) due to the lesser in-plume sampling periods (incomplete SMPS scans).

Those transects with sufficient plume data ( $>3$ data points per bin) are plotted against their accumulation-mode median diameter $D_{\mathrm{pm}}$ in Fig. 4 . We do not observe any discernible trend in size distribution with the distance from the source fires in either median diameter or number concentration. This lack of a trend suggests that the microphysical processing during the range of distances sampled has smaller effects on the size distribution than the variability between plumes for Flight b622. Similarly, small inter-transect variation was seen for Flight b623 (not shown). The median size distributions show no bias based on altitude or ascent/descent rate as an artefact of SMPS flow-rate fluctuations from altitude changes (not shown).

The composite median distribution across all plume sampling periods and both flights is shown in Fig. 5a. This characteristic size distribution is presented as a median value, minimizing the contributions of outlying data. Figure $5 b$ shows the same composite distribution normalized by $\mathrm{CO}$ concentration to attempt to account for differences in the amount of emissions from the source. The plume particle size distribution shows the median size distribution highlighted in black, with the 25th and 75th percentiles outlined in red. A clearly defined accumulation mode was identified centred at $D_{\text {pm }}=230 \mathrm{~nm}$ and with a modal width of 1.5 , based on a single lognormal-mode fit. Normalizing the plume distribution 


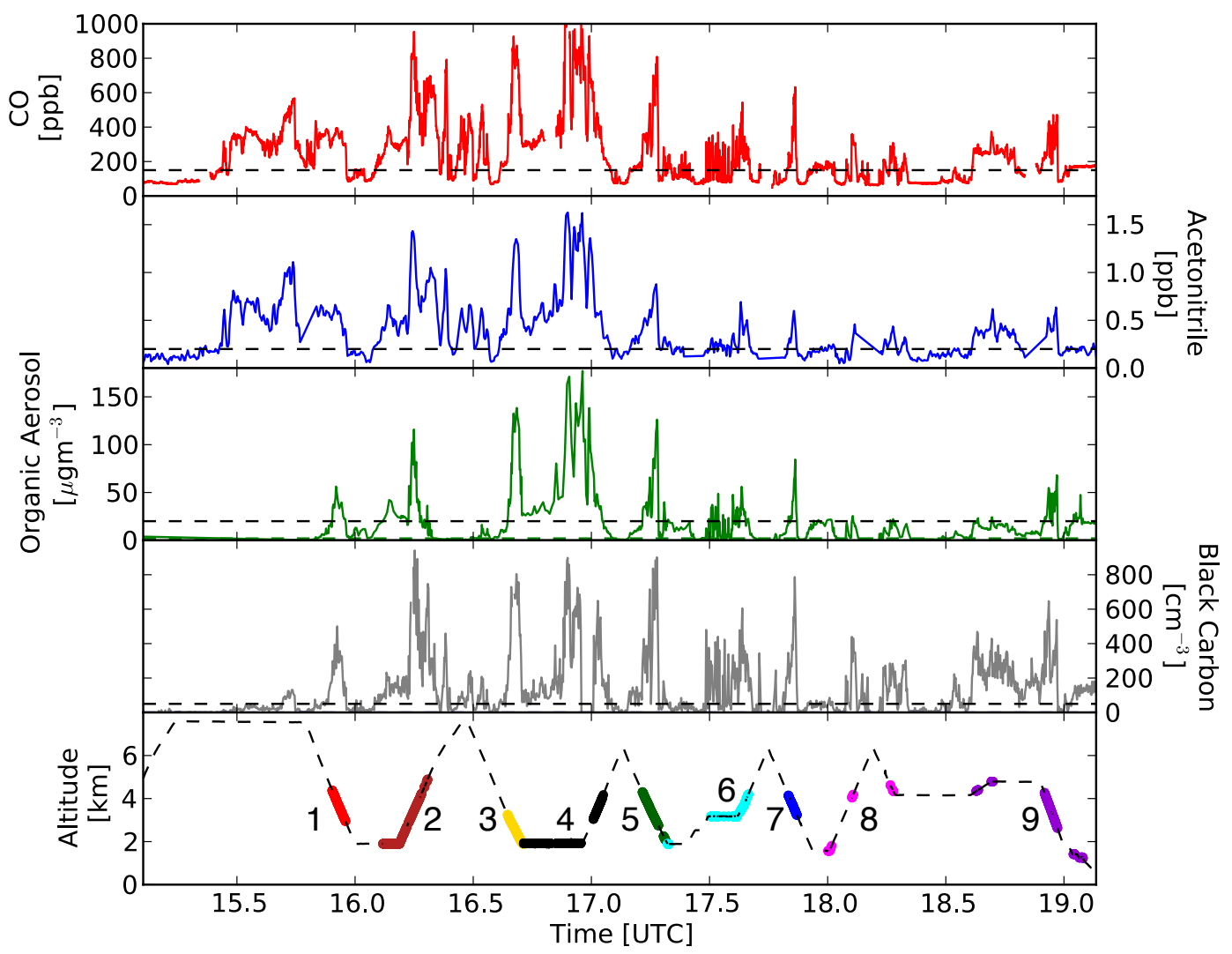

Figure 2. Time series of BORTAS-B aircraft measurements of biomass-burning tracer species for Flight b622. Threshold values (dashed black lines) were used across four species as plume criteria: (i) CO (red, threshold $=150 \mathrm{ppb}$ ), (ii) acetonitrile (blue, threshold $=200 \mathrm{pptv}$ ), (iii) organic aerosols (green, mass threshold $=20 \mu \mathrm{g} \mathrm{m}^{-3}$, at STP ), (iv) black carbon (grey, number threshold $=50 \mathrm{~cm}^{-3}$, at STP). The bottom panel shows flight altitude with plume sampling periods coloured. The plume data is further divided into transects (1-9 in red-violet).

by $\mathrm{CO}$ mixing ratio produced a very similar pattern shown in Fig. $5 \mathrm{~b}$ (accumulation mode: $D_{\mathrm{pm}}=230 \mathrm{~nm}, \sigma=1.4$ ). The composite background aerosol size distributions (sampling periods that failed the in-plume criteria) are seen in black (with 25th and 75th percentiles shown in grey) in Fig. 5a. It shows relatively constant $\mathrm{d} N / \mathrm{d} \log D_{\mathrm{p}}$ concentrations across the SMPS range and is lacking the concentrated accumulation mode found in-plume.

The aged composite size distribution and associated lognormal parameters are similar to those found in other field studies of aged biomass-burning emissions. Aged biomassburning size distributions compiled by Janhäll et al. (2010) for all different fuel types show a similar $D_{\text {pm }}$ to modal width ratio $\left(D_{\mathrm{pm}}=175-300 \mathrm{~nm}, \sigma=1.7-1.3\right)$. Capes et al. (2008) show a similar aged BB size-distribution median diameter over western Africa during the DABEX campaign $\left(D_{\mathrm{pm}}=240 \mathrm{~nm}\right)$. The ARCTAS-B campaign over northern Canada sampled similar boreal pyrogenic outflow and collected very similar aged distributions of $\mathrm{BC}$ and $\mathrm{OC}$ constituents $\left(D_{\mathrm{pm}}=224 \pm 14 \mathrm{~nm}, \sigma=1.33 \pm 0.05\right)$ (Kondo et al., 2011).
Of note in the BORTAS-B plume size distribution is the elevated number concentrations of small-diameter particles (20-90 nm), which form an elevated small-diameter "tail" of the distribution. These higher concentrations were not expected due to the high rate of removal of small particles by coagulation with the larger particles in the accumulation mode. We calculated first-order coagulational-loss timescales to investigate the timescale of the removal of these small particles by the larger plume particles. If these small particles were brought into the plume by entrainment of background air, there would be an associated amount of time before these particles were lost by coagulation. For the calculation, we assume Brownian coagulation of entrained background aerosol (bin range $20-90 \mathrm{~nm}$ ) with the observed in-plume SMPS data (90-333 nm) and with artificial largediameter bins from $330 \mathrm{~nm}$ to $1 \mu \mathrm{m}$ (six bins). These artificial bin concentrations were based on the accumulationmode lognormal fit and account for those particle concentrations at sizes larger than those measured by the SMPS but that nonetheless contribute to the coagulational scavenging of the small-diameter particles. Particles with diameters $>1 \mu \mathrm{m}$ were ignored since their relative scarcity relative to 


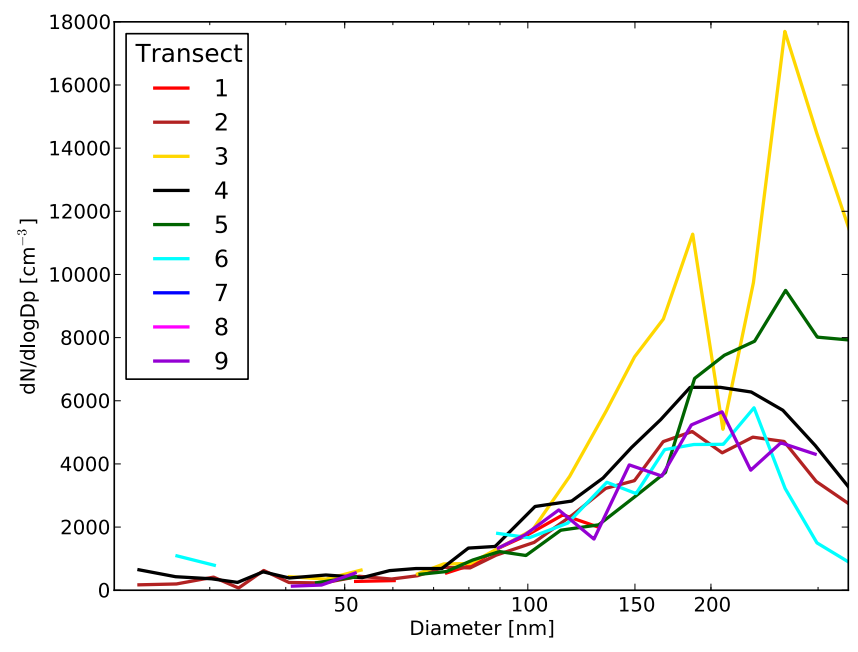

Figure 3. Median plume number-size distributions (corrected to $\mathrm{cm}^{-3}$ at STP) divided by transect for Flight b622. All size distributions show a consistent accumulation mode with $D_{\mathrm{pm}} \sim 220 \mathrm{~nm}$. Size bins with less than three data points in any transect are not shown, limiting the contributions from transects 1,7 and 8 . The composite plume size distribution for both flights b622 and b623 is seen in Fig. 5.

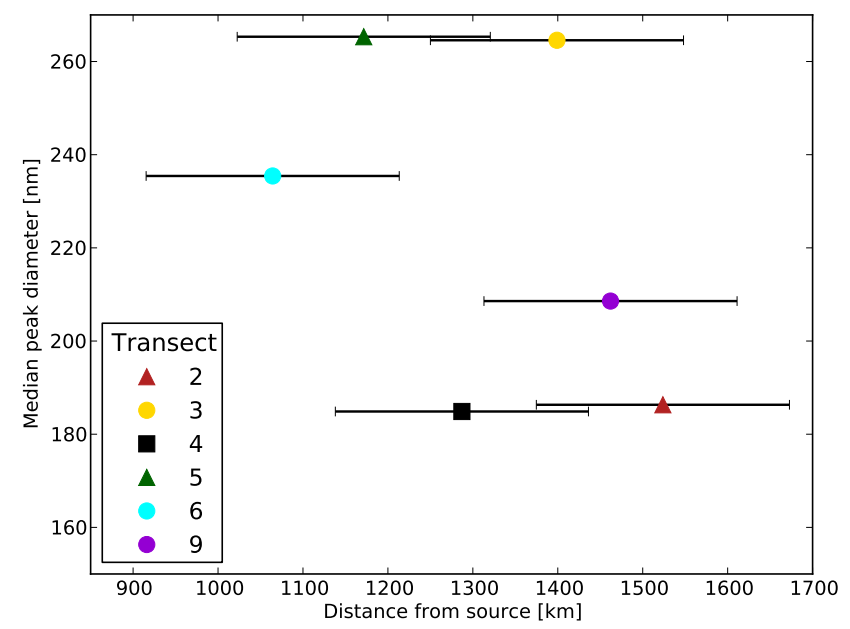

Figure 4. Accumulation-mode peak diameter by transect $(2-6,9)$ showing no significant trend with plume transport distance. All colours are the same as in Fig. 3. Distance from fire sources was estimated using transect midpoints and approximate source region area. Transects 1, 7 and 8 have insufficient accumulation-mode plume data and have been omitted. The uncertainty bars show uncertainty in the distance from the source $( \pm 150 \mathrm{~km})$.

the large number of accumulation-mode particles causes a negligible impact on the number-concentration-driven coagulation process.

The predicted concentrations of background aerosol remaining after 24, 36 and $48 \mathrm{~h}$ are shown in Fig. 6a. These times are within the estimated physical transport age ranges of the transects. After $12 \mathrm{~h}$, coagulation alone has already caused a significant decrease in the concentrations of the smallest measured particles, reducing them to levels well below the concentrations observed in-plume (red line). This deficit increases with time $(t=36 \mathrm{~h}, t=48 \mathrm{~h})$. The coagulation lifetimes of the particles in this diameter range (30$90 \mathrm{~nm}$ ) are seen in Fig. $6 \mathrm{~b}$ and extend into the tens of hours. Note that the concentrations of these small-diameter particles are similar in the plume compared to the background. This means that the entrainment rate of background air into the plume would need to be much faster than the coagulational loss timescales ( $\sim 5 \mathrm{~h}$ for $20 \mathrm{~nm}$ particles) in order for entrainment to sustain the number of small particles. If entrainment timescales were significantly shorter than $5 \mathrm{~h}$, the plume would almost completely disperse into the background within 1 day.

There are a number of mechanisms other than entrainment that could explain the higher tail concentrations found in-plume despite the short coagulation lifetimes. In-plume nucleation and subsequent growth to SMPS-detectable sizes could also partially account for sustained elevated smallparticle concentrations. Hennigan et al. (2012) showed with the FLAME-III chamber studies that in-plume nucleation was possible as a result of photochemical aging and SOA production in smoke plumes. Nucleation modes in association with smoke plumes have also been observed previously in field studies (Hobbs et al., 2003; Rissler et al., 2006). We attempted to determine the nucleation and growth rates required to sustain the observed concentration of small particles; however, the necessary condensational growth rates that were required to fit the observed data were unrealistically high, which we see as evidence against nucleation/growth being the primary source of the small particles. Thus, we are unsure of the source of these particles.

\subsection{Net production/loss of organic aerosol with time}

Enhancement ratios are a way of characterizing plume chemistry as a ratio of a specific species to a reference species. This was done for the sampled BORTAS pyrogenic outflow by taking the excess (background concentration removed) of the aerosol mass spectrometry organic aerosol normalized to the excess $\mathrm{CO}(\Delta \mathrm{OA} / \Delta \mathrm{CO})$. Only those data which were in excess of the mean background $\left(\mathrm{CO}=100 \mathrm{ppbv}, \mathrm{OA}=2 \mu \mathrm{g} \mathrm{m}^{-3}\right)$ were compiled. The characteristic $\triangle \mathrm{OA} / \triangle \mathrm{CO}$ ratio can be used as a comparison value between fires of different fuel type, phases or photochemical ages.

Since CO has a sufficiently long lifetime and is coemitted with $\mathrm{OA}$ in abundance at the source, any changes in the organic aerosol enhancement ratio over the lifetime of the plume are attributed to in-plume chemistry. Entrainment of background air into the most concentrated sections of the plumes is slow (timescale $>10 \mathrm{~h}$ ) and we consider any change in $\triangle \mathrm{OA} / \triangle \mathrm{CO}$ ratios to be attributable to in-plume processes only. The formation of secondary or- 

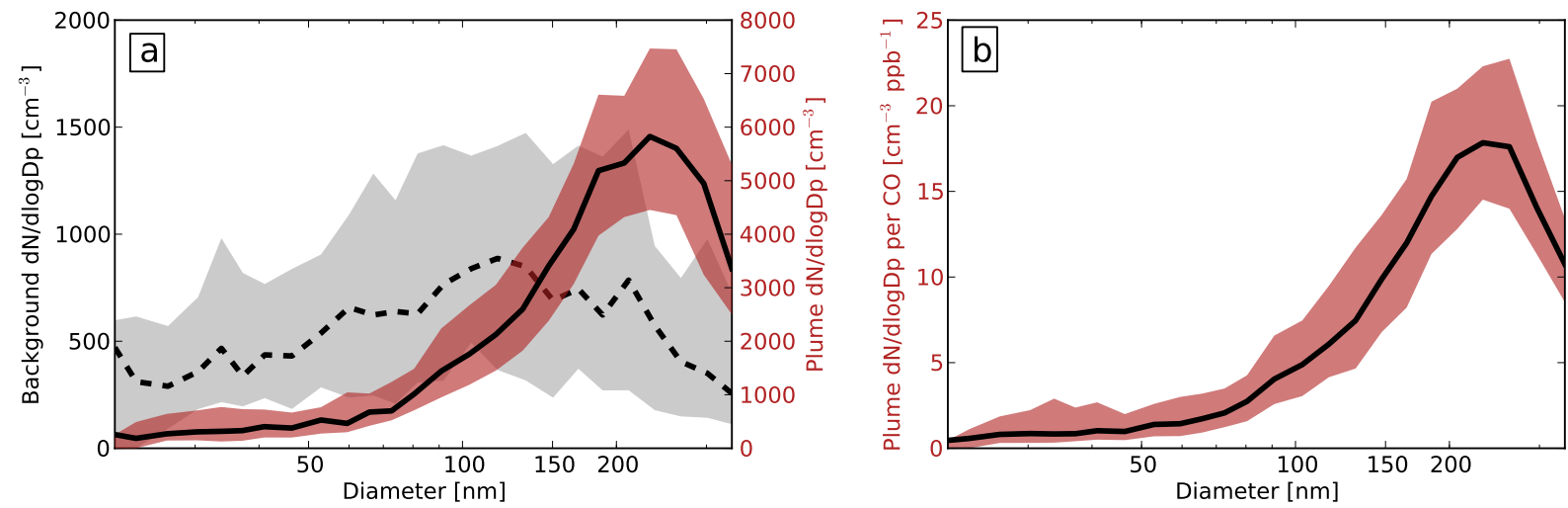

Figure 5. Composite median number-size distributions for Flights b622 and b623 ( $\mathrm{cm}^{-3}$ at STP). The in-plume (red) and background (grey) air distributions are shown as absolute concentrations (a). The in-plume distributions are also normalized by $\mathrm{CO}$ mixing ratio (b). The black lines are the median with the 25 th and 75 th percentiles overlain. The plume distributions have $D_{\mathrm{pm}}=230 \mathrm{~nm}$.
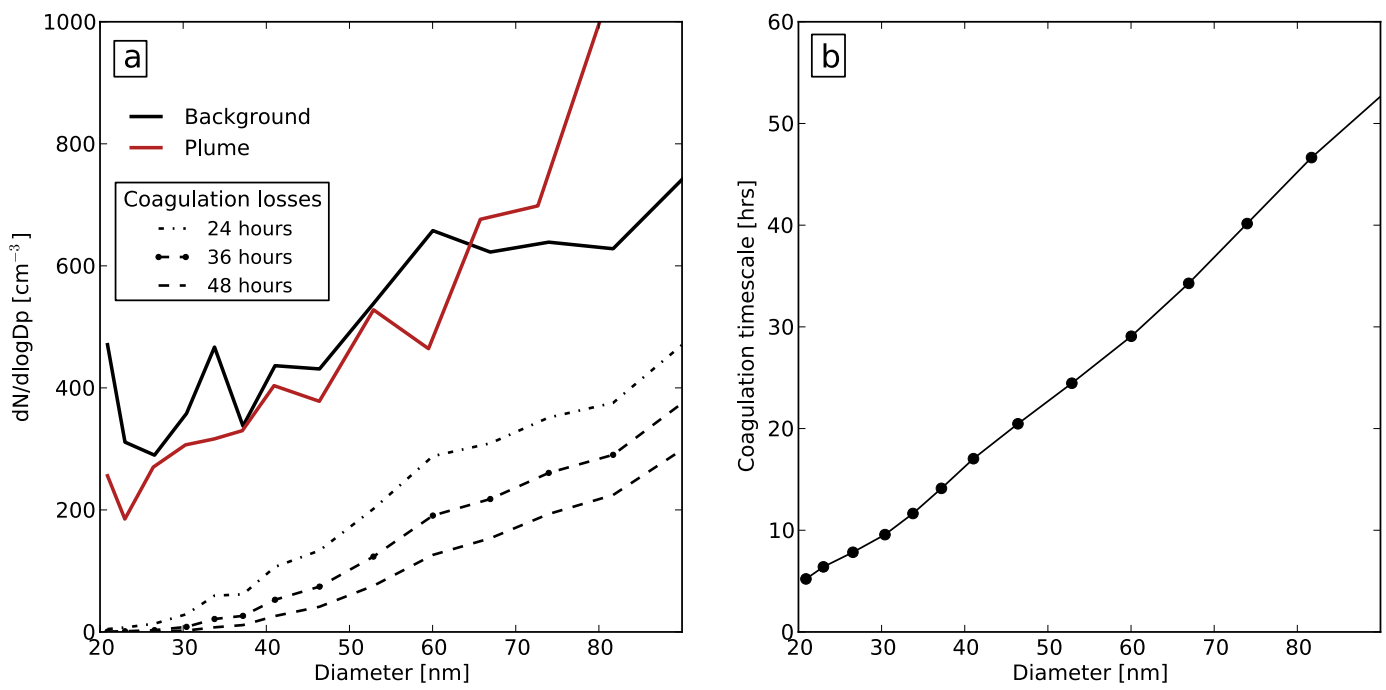

Figure 6. (a) shows background (black solid line) and plume (red line) median concentrations for small-particle diameters (20-90 nm). The black dashed lines are the number distributions after 24,36 and $48 \mathrm{~h}$ of coagulational losses by the plume accumulation mode (Fig. 5a) from the background level concentrations. These calculated concentrations are much lower than those found in-plume. (b) shows the coagulation lifetime as a function of particle diameter (on the order of tens of hours in this diameter range).

ganic aerosol is possible within the plume by oxidation of organic vapours to lower-volatility products. Evaporation of less-volatile POA during plume dilution competes with the SOA condensation. The net $\mathrm{OA}$ production is therefore $\Delta \mathrm{OA}_{\text {net }}=\mathrm{SOA}_{\text {prod }}-\mathrm{OA}_{\text {evap }}$. Changes in the $\Delta \mathrm{OA} / \Delta \mathrm{CO}$ ratio over time can therefore indicate which of the two processes is dominant.

The organic aerosol enhancement ratios for Flight b622 are shown in Fig. 7. There is a fairly pronounced altitude dependence, as seen in Fig. 7a, with several highaltitude $(\sim 7 \mathrm{~km})$ samples having fairly low excess organic aerosol, but significant $\Delta \mathrm{CO}(300 \mathrm{ppbv})$. This trend is featured in Franklin et al. (2014) where the high-altitude plume showed evidence of an aerosol rainout event causing low
$\Delta \mathrm{OA} / \Delta \mathrm{CO}$ ratios within the plume transected at those high altitudes.

We will focus on the lower-altitude plume where the aerosol was not rained out, so we employ a height cutoff of $4.6 \mathrm{~km}$ to restrict the enhancement ratio calculations to lower-altitude, OA-rich plumes least likely to have seen significant reduction in organic aerosol from wet deposition. The mean enhancement ratios by transect are seen in Fig. 7b (for transect locations see Fig. 1). Only those sampling periods that passed the $\mathrm{OA}$ and $\mathrm{CO}$ plume criteria (detailed above) are shown. The lower-altitude plume enhancement ratio shows correlations of $R^{2}>0.5$ for each transect with the exception of transect $8\left(R^{2}=0.26\right)$.

Figure 8 shows $\triangle \mathrm{OA} / \triangle \mathrm{CO}$ ratios as a function of the distance from the source fires (horizontal error bars corre- 

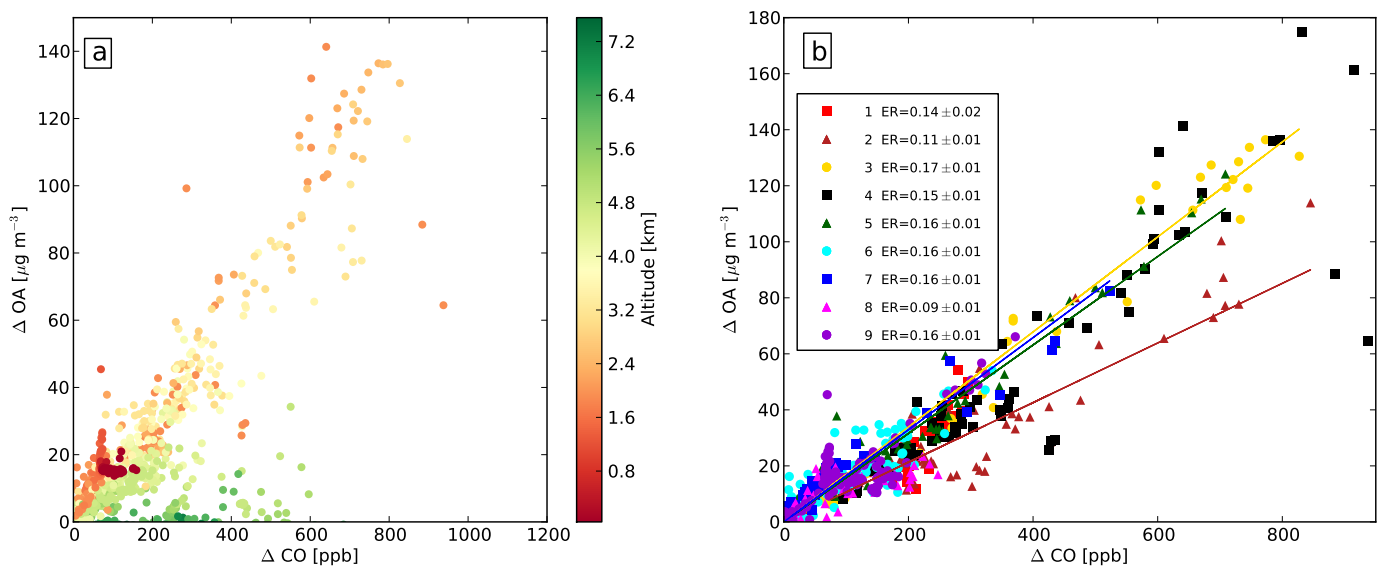

Figure 7. Enhancement ratios of $\Delta \mathrm{OA} / \Delta \mathrm{CO}$ ratios for Flight b622. (a) is coloured by altitude showing potential aerosol washout in the high-altitude plume (>4.6 km). (b) shows the ERs (enhancement ratios) separated by flight transect showing individual enhancement ratios of between 0.09 and $0.17 \pm 0.01 \mu \mathrm{g} \mathrm{m}^{-3} \mathrm{ppb}^{-1}$ with generally high correlation coefficients $\left(R^{2}>0.7\right)$ for the majority. The data points collected at altitudes greater than $4.6 \mathrm{~km}$ have been removed (as per a).

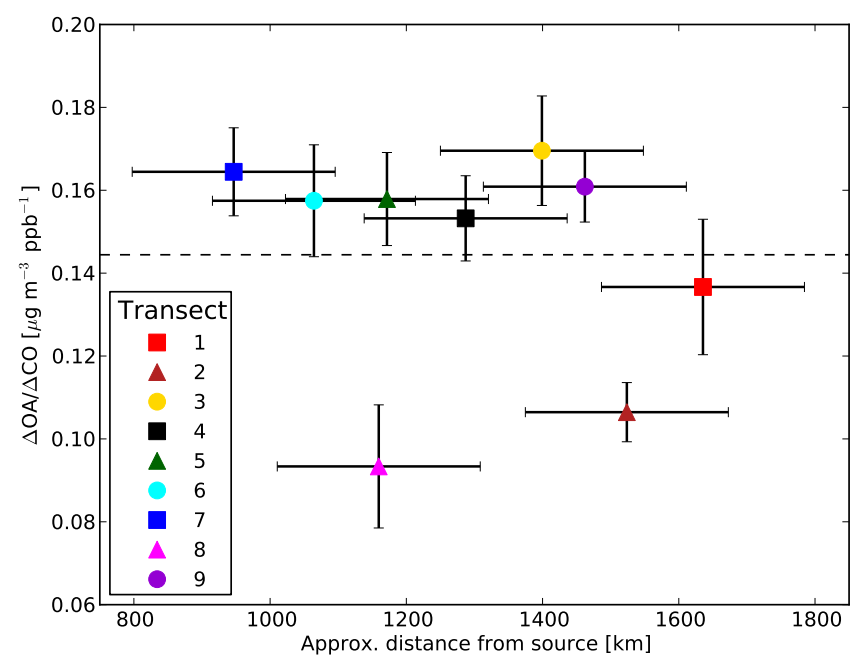

Figure 8. Transect $\Delta \mathrm{OA} / \Delta \mathrm{CO}$ enhancement ratios for Flight b622 as a function of the distance from the source fire region. The average ER is represented by the dashed black line $\left(0.144 \mu \mathrm{g} \mathrm{m}^{-3} \mathrm{ppb}^{-1}\right)$. There is no discernible trend in $\triangle \mathrm{OA}$ enhancement either by distance ( $x$ axis) or time (colours). The uncertainty bars display the uncertainty in distance and in fitted enhancement ratios.

spond to error due to the radius of the Ontario fire region, vertical error bars are calculated from transect data scatter). Compared across transects, the enhancement ratios show no significant trend (to $P$ value $=0.55$ ). The average enhancement ratio is $0.14 \pm 0.01\left(\mu \mathrm{g} \mathrm{m}^{-3} \mathrm{ppbv}^{-1}\right)$ and can be considered characteristic of the aged boreal plume during these BORTAS flights.

The lack of trend in Fig. 8 suggests that we cannot determine if there was any net production/evaporation of OA happening inside the plume over this sampling period (plume ages: 1-2 days). Any SOA produced photochemically inside the plume is either being accompanied by an opposing loss of POA or at such a rate that is below the observational variability over the sampled time period. The statistically invariant $\triangle \mathrm{OA} / \triangle \mathrm{CO}$ ratio does not discount evaporationcondensational cycling of POA and SOA, or the effects such recondensation would have on the size distribution (although there was no apparent trend in the size distribution either; Fig. 4). No increase in normalized excess OA fraction means significant levels of excess SOA were not likely to be driving condensational growth, ensuring that coagulation was dominating the size-distribution evolution during the period of aging between 1 and 2 days since emission.

Since no significant trend was found in size-distribution $D_{\mathrm{pm}}$ with distance from the source in the observations (>1000 km; see Fig. 4), any effect of POA-SOA cycling on the shape of the distribution cannot be isolated above the noise. However, it does not preclude that there was significant net OA production/evaporation that occurred prior to or after this observed period as has been observed in other BB field studies (e.g. Akagi et al., 2012; Yokelson et al., 2009). Thus, although evidence of photo-oxidation and chemical processing was observed in-plume by Parrington et al. (2013), any chemical composition impact on the size distribution at the ages observed here seems negligible.

\subsection{Estimation of the young biomass-burning size distribution}

In this section, we test the parameter space of our microphysical model to estimate the young(aged $\sim 1-3 \mathrm{~h}$ )-plume size distribution emitted from the source fires. We allowed the young biomass-burning size distribution to evolve for $48 \mathrm{~h}$ and compared the result to the observed SMPS plume composite distribution to isolate the optimal young-plume 

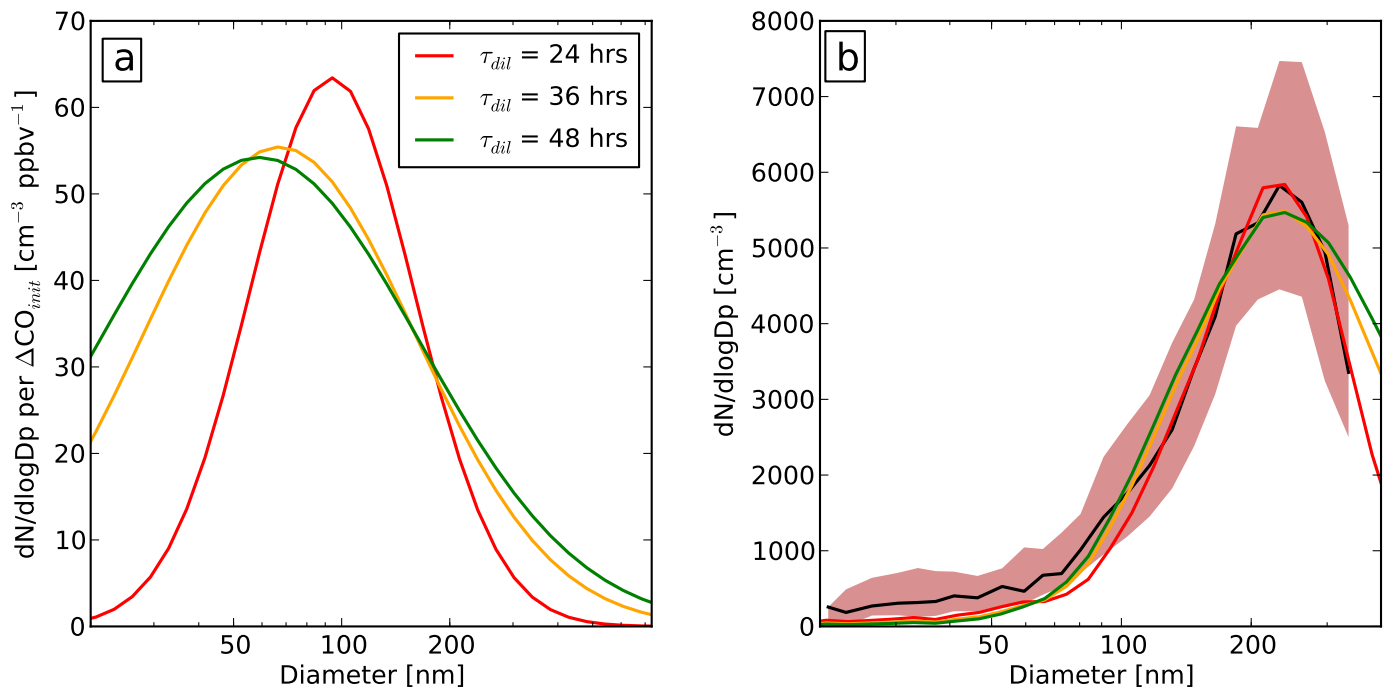

Figure 9. (a) shows the optimized young-plume size distributions for entrainment parameters $\tau_{\text {dil }}=24,36$, and $48 \mathrm{~h}$ as particle concentration per $\Delta$ COinit $\left(\mathrm{cm}^{-3} \mathrm{ppbv}^{-1}\right)$. (b) shows the final, modelled size distributions compared to the measured aged plume size distribution (black: median; red: quartiles).

size-distribution parameters. These were then compared to observed young BB size distributions for context.

The Lagrangian microphysical model was run for $48 \mathrm{~h}$ with fixed entrainment coefficients of $\tau_{\text {dil }}=24 \mathrm{~h}, \tau_{\text {dil }}=36 \mathrm{~h}$ and $\tau_{\text {dil }}=48 \mathrm{~h}$. Figure 9a shows the optimal young-plume distribution parameters that were obtained for each tested entrainment rate (with particle number concentration per coemitted $\mathrm{CO}$ above background). Figure $9 \mathrm{~b}$ shows the modelled aged distributions plotted with the measured distribution. None of the model runs can capture the elevated concentrations in the tail particles in the SMPS data, though this is expected due to the coagulation-dominant aging in the model (discussed above) and adds further uncertainty to the existence of this small tail.

The young-plume size distributions are unimodal with median diameters of 94,67 , and $59 \mathrm{~nm}$ for $\tau_{\mathrm{dil}}=24 \mathrm{~h}, \tau_{\mathrm{dil}}=36 \mathrm{~h}$ and $\tau_{\text {dil }}=48 \mathrm{~h}$, respectively $(\sigma=1.7,2.1$, and 2.8 , respectively). The higher entrainment rate of background aerosol requires the young-plume distribution to be narrower (lower $\sigma)$ and have an initial median diameter closer to the final diameter $\left(D_{\text {pfinal }}=230 \mathrm{~nm}\right)$. The initial number concentrations in the young plume were found to be optimized at 62500 , 80000 , and $115000\left(\mathrm{~cm}^{-3}\right)$ for $\tau_{\text {dil }}=48 \mathrm{~h}, \tau_{\text {dil }}=36 \mathrm{~h}$ and $\tau_{\text {dil }}=24 \mathrm{~h}$, respectively. The initial higher concentrations, narrower modal width, and larger median diameter are required for the higher entrainment rates to account for the more rapid plume dilution and subsequently the slowing of the coagulation rates. Normalized to estimated freshly emitted excess $\mathrm{CO}$, the young-plume number concentrations are 37,53 , and $60 \mathrm{~cm}^{-3} \mathrm{ppbv}^{-1}$ (for $\tau_{\mathrm{dil}}=24 \mathrm{~h}, \tau_{\mathrm{dil}}=36 \mathrm{~h}$, and $\tau_{\text {dil }}=48 \mathrm{~h}$, respectively; see Fig. 9a). The similar magnitudes of these normalized size distributions indicate a relatively ro- bust particle / $\mathrm{CO}$ ratio regardless of the dilution parameter; though, in the absence of the source fire fuel densities, a direct comparison to emission factors $\left(\mathrm{kg}^{-1}\right)$ cannot be made.

As the exact aging time and dilution profiles are unknown in addition to uncertainties in the plume age, we cannot say with certainty which of these estimates is best; however, these results compare to the field observations presented in Janhäll et al. (2010) for fresh plume smoke (range: $D_{\mathrm{pm}}=100-150 \mathrm{~nm}$ ) and to small-scale lab experiments measuring fresh smoke (range: $D_{\mathrm{pm}}=30-90 \mathrm{~nm}$ ) (Hosseini et al., 2010). Capes et al. (2008) conducted a similar fresh-plume size-distribution estimate from their observed DABEX aged African smoke data using a coagulation box model without dilution. Their estimates for very fresh smoke have a much smaller $D_{\mathrm{pm}}(\sim 30 \mathrm{~nm})$.

The plume size distributions modelled here are very sensitive to microphysical processes directly after emission. Very close to the source, rapid dilution and condensation (due to cooling) may occur, which are not captured by the coagulation/dilution model we have developed. Thus, the modelled plumes are better categorized as "young" rather than freshly emitted. The young-plume distributions in this study neglect any immediate effects of condensation and/or evaporation of $\mathrm{OA}$ on the size distribution during cooling and dilution, respectively, and focus on the effects of coagulation which shape the size distribution over a longer timescale $(\sim 10 \mathrm{~h})$. There is therefore an associated uncertainty in the young distributions due to the exclusion of condensational growth from the model, despite evidence of its effects on BB particle sizes especially during the first hours of aging (e.g. Reid et al., 1998). 


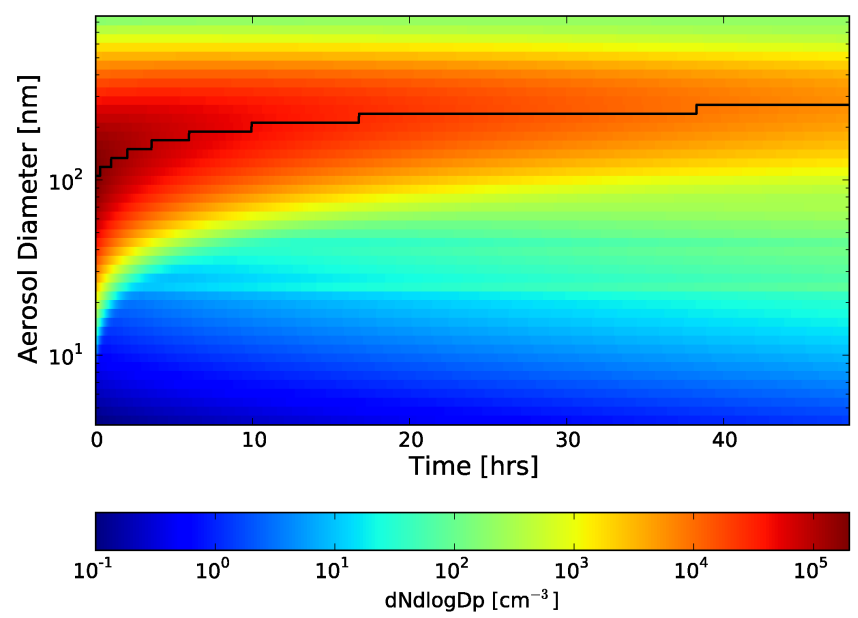

Figure 10. Plot of modelled size-distribution evolution for $\tau_{\text {dil }}=36 \mathrm{~h}$. The black line shows the peak diameter at each time step $(\Delta \mathrm{t}=10 \mathrm{~s})$. The young-plume size distribution has optimal initial parameters: $D_{\mathrm{pm}}=67 \mathrm{~nm}, \sigma=2.4, \mathrm{~N}_{0}=80000 \mathrm{~cm}^{-3}$.

Figure 10 shows a time series of the optimal modelled size distribution for $\tau_{\mathrm{dil}}=36 \mathrm{~h}$ over the $48 \mathrm{~h}$ period. The median diameter growth (black line) occurs more rapidly during the early stages of the plume due to the higher particle concentrations before significant dilution. Overall, $80 \%$ of the final median diameter is achieved within $10 \mathrm{~h}$ of coagulation processing. Less drastic but similar rapid growth by coagulation was seen by Capes et al. (2008) in their coagulation box model. This quick size-distribution evolution within the early plume stages suggests that large grid box models (global, regional) should be using aged biomass-burning size distributions as input. Figure 10 also shows the size-distribution growth slowing considerably as the particle concentrations decrease and perhaps can provide an explanation for the lack of strong trends in the observed BORTAS $D_{\text {pm }}$ across transects (Fig. 4), which were already aged between 1 and 2 days when they were sampled.

\section{Conclusions}

The BORTAS-B campaign provided the opportunity to collect numerous gaseous and aerosol measurements from aged North American biomass-burning plumes in July 2011. The boreal fire emissions in northwestern Ontario were transported (1-2 days) downwind to where they were sampled by the FAAM BAe-146 research aircraft. We analysed the plume data from two research flights (b622 and b623) and found little variation in size distributions between transects.

A characteristic size distribution consistent between flights and transects was dominated by the accumulation mode with $D_{\mathrm{pm}}=230 \mathrm{~nm}$ and with $\sigma=1.5$. This unimodal result is consistent with aged biomass-burning observations found globally in the previous field studies (Capes et al., 2008; Janhäll et al., 2010; Kondo et al., 2011).

We also found elevated concentrations of small-diameter particles in the plume contrary to their coagulation lifetimes associated with the biomass-burning-associated accumulation mode. We were not able to explain such concentrations by entrainment of background aerosol alone. The presence of such concentrations in the size-distribution tail remains inconclusive.

The $\triangle \mathrm{OA} / \triangle \mathrm{CO}$ enhancement ratios across Flight b622 show a strong linear correlation below $4.6 \mathrm{~km}\left(R^{2}>0.50\right)$ with values between $(0.09$ and 0.17$) \pm 0.01 \mu \mathrm{g} \mathrm{m}^{-3} \mathrm{ppbv}^{-1}$. We found no trend in transect enhancement ratios with distance from the source, indicating no significant net SOA production in-plume over the sampling period, though this does not preclude OA production or loss during earlier stages of aging.

We used a microphysical model to estimate the youngplume size distribution associated with the BORTAS-B observations. Optimizing lognormal parameters for different assumed dilution coefficients ( $\tau_{\mathrm{dil}}=24,36,48 \mathrm{~h}$ ), the youngplume size distribution had $D_{\mathrm{pm}}=59-94 \mathrm{~nm}, \sigma=2.8-1.7$, and $\mathrm{N}_{0}=62500-115000 \mathrm{~cm}^{-3}\left(37-60 \mathrm{~cm}^{-3} \mathrm{ppbv}^{-1}\right.$ normalized by initial co-emitted excess $\mathrm{CO}$ ). Though the model lacks condensation and chemical considerations, processing through coagulation and dilution alone led to $80 \%$ of the observed $48 \mathrm{~h}$ median-diameter growth within the first $10 \mathrm{~h}$. This suggests that global climate models should be using coagulation-aged BB size-distribution inputs to account for the rapid evolution in plume particle size occurring on scales smaller than the grid box length.

Acknowledgements. K. Sakamoto was supported by an NSERC PGS-M graduate fellowship.

Edited by: P. Monks

\section{References}

Adler, G., Flores, J. M., Abo Riziq, A., Borrmann, S., and Rudich, Y.: Chemical, physical, and optical evolution of biomass burning aerosols: a case study, Atmos. Chem. Phys., 11, 1491-1503, doi:10.5194/acp-11-1491-2011, 2011.

Akagi, S. K., Craven, J. S., Taylor, J. W., McMeeking, G. R., Yokelson, R. J., Burling, I. R., Urbanski, S. P., Wold, C. E., Seinfeld, J. H., Coe, H., Alvarado, M. J., and Weise, D. R.: Evolution of trace gases and particles emitted by a chaparral fire in California, Atmos. Chem. Phys., 12, 1397-1421, doi:10.5194/acp-12-13972012, 2012.

Alonso-Blanco, E.: Impact of Biomass Burning on Aerosol Size Distribution, Aerosol Optical Properties and Associated Radiative Forcing, Aerosol Air Qual. Res., 14, 708-724, doi:10.4209/aaqr.2013.05.0163, 2014. 
Andreae, M. O. and Merlet, P.: Emission of trace gases and aerosols from biomass burning, Global Biogeochem. Cy., 15, 955-966, doi:10.1029/2000GB001382, 2001.

Andreae, M. O., Artaxo, P., Fischer, H., Freitas, S. R., Grégoire, J.-M., Hansel, A., Hoor, P., Kormann, R., Krejci, R., Lange, L., Lelieveld, J., Lindinger, W., Longo, K., Peters, W., de Reus, M., Scheeren, B., Silva Dias, M. A. F., Ström, J., van Velthoven, P. F. J., and Williams, J.: Transport of biomass burning smoke to the upper troposphere by deep convection in the equatorial region, Geophys. Res. Lett., 28, 951-954, doi:10.1029/2000GL012391, 2001.

Bauer, S. E., Menon, S., Koch, D., Bond, T. C., and Tsigaridis, K.: A global modeling study on carbonaceous aerosol microphysical characteristics and radiative effects, Atmos. Chem. Phys., 10, 7439-7456, doi:10.5194/acp-10-7439-2010, 2010.

Capes, G., Johnson, B., McFiggans, G., Williams, P. I., Haywood, J., and Coe, H.: Aging of biomass burning aerosols over West Africa: Aircraft measurements of chemical composition, microphysical properties, and emission ratios, J. Geophys. Res., 113, D00C15, doi:10.1029/2008JD009845, 2008.

Carrico, C. M., Petters, M. D., Kreidenweis, S. M., Sullivan, A. P., McMeeking, G. R., Levin, E. J. T., Engling, G., Malm, W. C., and Collett Jr., J. L.: Water uptake and chemical composition of fresh aerosols generated in open burning of biomass, Atmos. Chem. Phys., 10, 5165-5178, doi:10.5194/acp-10-5165-2010, 2010.

Chen, W. T., Lee, Y. H., Adams, P. J., Nenes, A., and Seinfeld, J. H.: Will black carbon mitigation dampen aerosol indirect forcing?, Geophys. Res. Lett., 37, L09801, doi:10.1029/2010GL042886, 2010.

Cubison, M. J., Ortega, A. M., Hayes, P. L., Farmer, D. K., Day, D., Lechner, M. J., Brune, W. H., Apel, E., Diskin, G. S., Fisher, J. A., Fuelberg, H. E., Hecobian, A., Knapp, D. J., Mikoviny, T., Riemer, D., Sachse, G. W., Sessions, W., Weber, R. J., Weinheimer, A. J., Wisthaler, A., and Jimenez, J. L.: Effects of aging on organic aerosol from open biomass burning smoke in aircraft and laboratory studies, Atmos. Chem. Phys., 11, 12049-12064, doi:10.5194/acp-11-12049-2011, 2011.

DeCarlo, P. F., Ulbrich, I. M., Crounse, J., de Foy, B., Dunlea, E. J., Aiken, A. C., Knapp, D., Weinheimer, A. J., Campos, T., Wennberg, P. O., and Jimenez, J. L.: Investigation of the sources and processing of organic aerosol over the Central Mexican Plateau from aircraft measurements during MILAGRO, Atmos. Chem. Phys., 10, 5257-5280, doi:10.5194/acp-10-52572010, 2010.

Engelhart, G. J., Hennigan, C. J., Miracolo, M. A., Robinson, A. L., and Pandis, S. N.: Cloud condensation nuclei activity of fresh primary and aged biomass burning aerosol, Atmos. Chem. Phys., 12, 7285-7293, doi:10.5194/acp-12-7285-2012, 2012.

Franklin, J. E., Drummond, J. R., Griffin, D., Pierce, J. R., Waugh, D. L., Palmer, P. I., Parrington, M., Lee, J. D., Lewis, A. C., Rickard, A. R., Taylor, J. W., Allan, J. D., Coe, H., Walker, K. A., Chisholm, L., Duck, T. J., Hopper, J. T., Blanchard, Y., Gibson, M. D., Curry, K. R., Sakamoto, K. M., Lesins, G., Dan, L., Kliever, J., and Saha, A.: A case study of aerosol scavenging in a biomass burning plume over eastern Canada during the 2011 BORTAS field experiment, Atmos. Chem. Phys., 14, 8449-8460, doi:10.5194/acp-14-8449-2014, 2014

Fuchs, N. A.: The Mechanics of Aerosols, Oxford: Pergamon Press., 408 pp., 1964.
Grieshop, A. P., Logue, J. M., Donahue, N. M., and Robinson, A. L.: Laboratory investigation of photochemical oxidation of organic aerosol from wood fires 1: measurement and simulation of organic aerosol evolution, Atmos. Chem. Phys., 9, 1263-1277, doi:10.5194/acp-9-1263-2009, 2009.

Haywood, J. and Boucher, O.: Estimates of the direct and indirect radiative forcing due to tropospheric aerosols: a review, Rev. Geophys., 38, 513-543, doi:10.1029/1999RG000078, 2000.

Hecobian, A., Liu, Z., Hennigan, C. J., Huey, L. G., Jimenez, J. L., Cubison, M. J., Vay, S., Diskin, G. S., Sachse, G. W., Wisthaler, A., Mikoviny, T., Weinheimer, A. J., Liao, J., Knapp, D. J., Wennberg, P. O., Kürten, A., Crounse, J. D., Clair, J. St., Wang, Y., and Weber, R. J.: Comparison of chemical characteristics of 495 biomass burning plumes intercepted by the NASA DC-8 aircraft during the ARCTAS/CARB-2008 field campaign, Atmos. Chem. Phys., 11, 13325-13337, doi:10.5194/acp-1113325-2011, 2011.

Hennigan, C. J., Miracolo, M. A., Engelhart, G. J., May, A. A., Presto, A. A., Lee, T., Sullivan, A. P., McMeeking, G. R., Coe, H., Wold, C. E., Hao, W.-M., Gilman, J. B., Kuster, W. C., de Gouw, J., Schichtel, B. A., Collett Jr., J. L., Kreidenweis, S. M., and Robinson, A. L.: Chemical and physical transformations of organic aerosol from the photo-oxidation of open biomass burning emissions in an environmental chamber, Atmos. Chem. Phys., 11, 7669-7686, doi:10.5194/acp-11-7669-2011, 2011.

Hennigan, C. J., Westervelt, D. M., Riipinen, I., Engelhart, G. J., Lee, T., Collett, J. L., Pandis, S. N., Adams, P. J., and Robinson, A. L.: New particle formation and growth in biomass burning plumes: An important source of cloud condensation nuclei, Geophys. Res. Lett., 39, L09805, doi:10.1029/2012GL050930, 2012.

Heringa, M. F., DeCarlo, P. F., Chirico, R., Tritscher, T., Dommen, J., Weingartner, E., Richter, R., Wehrle, G., Prévôt, A. S. H., and Baltensperger, U.: Investigations of primary and secondary particulate matter of different wood combustion appliances with a high-resolution time-of-flight aerosol mass spectrometer, Atmos. Chem. Phys., 11, 5945-5957, doi:10.5194/acp-11-59452011, 2011.

Hobbs, P. V., Sinha, P., Yokelson, R. J., Christian, T. J., Blake, D. R., Gao, S., Kirchstetter, T. W., Novakov, T., and Pilewskie, P.: Evolution of gases and particles from a savanna fire in South Africa, J. Geophys. Res., 108, 8485, doi:10.1029/2002JD002352, 2003.

Holzinger, R., Williams, J., Salisbury, G., Klüpfel, T., de Reus, M., Traub, M., Crutzen, P. J., and Lelieveld, J.: Oxygenated compounds in aged biomass burning plumes over the Eastern Mediterranean: evidence for strong secondary production of methanol and acetone, Atmos. Chem. Phys., 5, 39-46, doi:10.5194/acp-5-39-2005, 2005.

Hosseini, S., Li, Q., Cocker, D., Weise, D., Miller, A., Shrivastava, M., Miller, J. W., Mahalingam, S., Princevac, M., and Jung, H.: Particle size distributions from laboratory-scale biomass fires using fast response instruments, Atmos. Chem. Phys., 10, 80658076, doi:10.5194/acp-10-8065-2010, 2010.

Hudson, P. K., Murphy, D. M., Cziczo, D. J., Thomson, D. S., de Gouw, J. A., Warneke, C., Holloway, J., Jost, H.-J., and Hübler, G.: Biomass-burning particle measurements: Characteristic composition and chemical processing, J. Geophys. Res., 109, D23S27, doi:10.1029/2003JD004398, 2004.

Huffman, J. A., Docherty, K. S., Mohr, C., Cubison, M. J., Ulbrich, I. M., Ziemann, P. J., Onasch, T. B., and Jimenez, J. 
L.: Chemically-Resolved Volatility Measurements of Organic Aerosol from Different Sources, Environ. Sci. Technol., 43, 5351-5357, doi:10.1021/es803539d, 2009.

Jacobson, M. Z.: Strong radiative heating due to the mixing state of black carbon in atmospheric aerosols, Nature, 409, 695-697, 2001.

Janhäll, S., Andreae, M. O., and Pöschl, U.: Biomass burning aerosol emissions from vegetation fires: particle number and mass emission factors and size distributions, Atmos. Chem. Phys., 10, 1427-1439, doi:10.5194/acp-10-1427-2010, 2010.

Klug,W. : A method for determining diffusion conditions from synoptic observations, Staub-Reinhalt. Luft, 29, 14-20, 1969.

Kondo, Y., Matsui, H., Moteki, N., Sahu, L., Takegawa, N., Kajino, M., Zhao, Y., Cubison, M. J., Jimenez, J. L., Vay, S., Diskin, G. S., Anderson, B., Wisthaler, A., Mikoviny, T., Fuelberg, H. E., Blake, D. R., Huey, G., Weinheimer, A. J., Knapp, D. J., and Brune, W. H.: Emissions of black carbon, organic, and inorganic aerosols from biomass burning in North America and Asia in 2008, J. Geophys. Res., 116, D08204, doi:10.1029/2010JD015152, 2011.

Jolleys, M. D., Coe, H., McFiggans, G., Taylor, J. W., O'Shea, S. J., Le Breton, M., Bauguitte, S. J.-B., Moller, S., Di Carlo, P., Aruffo, E., Palmer, P. I., and Lee, J. D.: Properties and evolution of biomass burning organic aerosol from Canadian boreal forest fires, Atmos. Chem. Phys. Discuss., 14, 25095-25138, doi:10.5194/acpd-14-25095-2014, 2014.

Lee, L. A., Pringle, K. J., Reddington, C. L., Mann, G. W., Stier, P., Spracklen, D. V., Pierce, J. R., and Carslaw, K. S.: The magnitude and causes of uncertainty in global model simulations of cloud condensation nuclei, Atmos. Chem. Phys., 13, 8879-8914, doi:10.5194/acp-13-8879-2013, 2013.

Lee, S., Kim, H. K., Yan, B., Cobb, C. E., Hennigan, C., Nichols, S., Chamber, M., Edgerton, E. S., Jansen, J. J., Hu, Y., Zheng, M., Weber, R. J., and Russell, A. G.: Diagnosis of aged prescribed burning plumes impacting an urban area., Environ. Sci. Technol., 42, 1438-1444, 2008.

Leppä, J., Mui, W., Grantz, A. M., and Flagan, R. C.: OP10-5, Importance of charger ion properties in size distribution measurements, International Aerosol Conference, 28 August-2 September, BEXCO, Busan, Korea, 2014.

Levin, E. J. T., McMeeking, G. R., Carrico, C. M., Mack, L. E., Kreidenweis, S. M., Wold, C. E., Moosmüller, H., Arnott, W. P., Hao, W. M., Collett, J. L., and Malm, W. C.: Biomass burning smoke aerosol properties measured during Fire Laboratory at Missoula Experiments (FLAME), J. Geophys. Res., 115, D18210, doi:10.1029/2009JD013601, 2010.

López-Yglesias, X. and Flagan, R. C.: Ion-Aerosol Flux Coefficients and the Steady-State Charge Distribution of Aerosols in a Bipolar Ion Environment, Aerosol Sci. Technol., 47, 688-704, doi:10.1080/02786826.2013.783684, 2013.

May, A. A., Levin, E. J. T., Hennigan, C. J., Riipinen, I., Lee, T., Collett, J. L., Jimenez, J. L., Kreidenweis, S. M., and Robinson, A. L.: Gas-particle partitioning of primary organic aerosol emissions: 3. Biomass burning, J. Geophys. Res.-Atmos., 118, 11327-11338, doi:10.1002/jgrd.50828, 2013.

Myhre, G., D. Shindell, F.-M. Bréon, W. Collins, J. Fuglestvedt, J. Huang, D. Koch, J.-F. Lamarque, D. Lee, B. Mendoza, T. Nakajima, A. Robock, G. Stephens, T. Takemura and H. Zhang: Anthropogenic and Natural Radiative Forcing, in: Climate Change
2013: The Physical Science Basis. Contribution of Working Group I to the Fifth Assessment Report of the Intergovernmental Panel on Climate Change, edited by: Stocker, T. F., Qin, D., Plattner, G.-K., Tignor, M., Allen, S. K., Boschung, J., Nauels, A., Xia, Y., Bex, V., and Midgley, P. M., Cambridge University Press, Cambridge, United Kingdom and New York, NY, USA, 659-740, 2013.

Okoshi, R., Rasheed, A., Chen Reddy, G., McCrowey, C. J., and Curtis, D. B.: Size and mass distributions of ground-level sub-micrometer biomass burning aerosol from small wildfires, Atmos. Environ., 89, 392-402, doi:10.1016/j.atmosenv.2014.01.024, 2014.

Ontario Ministry of Natural Resources and Forestry, 2011 Forest Fire Summary, available at: https://www.ontario.ca/ law-and-safety/forest-fires (last access: 12 February 2015), 2012.

Ortega, A. M., Day, D. A., Cubison, M. J., Brune, W. H., Bon, D., de Gouw, J. A., and Jimenez, J. L.: Secondary organic aerosol formation and primary organic aerosol oxidation from biomass-burning smoke in a flow reactor during FLAME-3, Atmos. Chem. Phys., 13, 11551-11571, doi:10.5194/acp-1311551-2013, 2013.

Palmer, P. I., Parrington, M., Lee, J. D., Lewis, A. C., Rickard, A. R., Bernath, P. F., Duck, T. J., Waugh, D. L., Tarasick, D. W., Andrews, S., Aruffo, E., Bailey, L. J., Barrett, E., Bauguitte, S. J.-B., Curry, K. R., Di Carlo, P., Chisholm, L., Dan, L., Forster, G., Franklin, J. E., Gibson, M. D., Griffin, D., Helmig, D., Hopkins, J. R., Hopper, J. T., Jenkin, M. E., Kindred, D., Kliever, J., Le Breton, M., Matthiesen, S., Maurice, M., Moller, S., Moore, D. P., Oram, D. E., O'Shea, S. J., Owen, R. C., Pagniello, C. M. L. S., Pawson, S., Percival, C. J., Pierce, J. R., Punjabi, S., Purvis, R. M., Remedios, J. J., Rotermund, K. M., Sakamoto, K. M., da Silva, A. M., Strawbridge, K. B., Strong, K., Taylor, J., Trigwell, R., Tereszchuk, K. A., Walker, K. A., Weaver, D., Whaley, C., and Young, J. C.: Quantifying the impact of BOReal forest fires on Tropospheric oxidants over the Atlantic using Aircraft and Satellites (BORTAS) experiment: design, execution and science overview, Atmos. Chem. Phys., 13, 6239-6261, doi:10.5194/acp-13-6239-2013, 2013.

Parrington, M., Palmer, P. I., Lewis, A. C., Lee, J. D., Rickard, A. R., Di Carlo, P., Taylor, J. W., Hopkins, J. R., Punjabi, S., Oram, D. E., Forster, G., Aruffo, E., Moller, S. J., Bauguitte, S. J.-B., Allan, J. D., Coe, H., and Leigh, R. J.: Ozone photochemistry in boreal biomass burning plumes, Atmos. Chem. Phys., 13, 73217341, doi:10.5194/acp-13-7321-2013, 2013.

Parrish, D. D., Stohl, A., Forster, C., Atlas, E. L., Blake, D. R., Goldan, P. D., Kuster, W. C., and de Gouw, J. A.: Effects of mixing on evolution of hydrocarbon ratios in the troposphere, J. Geophys. Res., 112, D10S34, doi:10.1029/2006JD007583, 2007.

Petters, M. D. and Kreidenweis, S. M.: A single parameter representation of hygroscopic growth and cloud condensation nucleus activity, Atmos. Chem. Phys., 7, 1961-1971, doi:10.5194/acp-71961-2007, 2007.

Petters, M. D., Carrico, C. M., Kreidenweis, S. M., Prenni, A. J., DeMott, P. J., Collett, J. L., and Moosmüller, H.: Cloud condensation nucleation activity of biomass burning aerosol, J. Geophys. Res., 114, D22205, doi:10.1029/2009JD012353, 2009.

Pierce, J. R., Chen, K., and Adams, P. J.: Contribution of primary carbonaceous aerosol to cloud condensation nuclei: processes 
and uncertainties evaluated with a global aerosol microphysics model, Atmos. Chem. Phys., 7, 5447-5466, doi:10.5194/acp-75447-2007, 2007.

Reddington, C. L., Carslaw, K. S., Spracklen, D. V., Frontoso, M. G., Collins, L., Merikanto, J., Minikin, A., Hamburger, T., Coe, H., Kulmala, M., Aalto, P., Flentje, H., Plass-Dülmer, C., Birmili, W., Wiedensohler, A., Wehner, B., Tuch, T., Sonntag, A., O’Dowd, C. D., Jennings, S. G., Dupuy, R., Baltensperger, U., Weingartner, E., Hansson, H.-C., Tunved, P., Laj, P., Sellegri, K., Boulon, J., Putaud, J.-P., Gruening, C., Swietlicki, E., Roldin, P., Henzing, J. S., Moerman, M., Mihalopoulos, N., Kouvarakis, G., Ždímal, V., Zíková, N., Marinoni, A., Bonasoni, P., and Duchi, R.: Primary versus secondary contributions to particle number concentrations in the European boundary layer, Atmos. Chem. Phys., 11, 12007-12036, doi:10.5194/acp-11-12007-2011, 2011.

Reid, J. S., Hobbs, P., and Ferek, R.: Physical, chemical, and optical properties of regional hazes dominated by smoke in Brazil, J. Geophys. Res., 103, 32059-32080, doi:10.1029/98JD00458, 1998.

Reid, J. S., Koppmann, R., Eck, T. F., and Eleuterio, D. P.: A review of biomass burning emissions part II: intensive physical properties of biomass burning particles, Atmos. Chem. Phys., 5, 799825, doi:10.5194/acp-5-799-2005, 2005.

Reid, J. S., Hyer, E. J., Prins, E. M., Westphal, D. L., Zhang, J., Wang, J., Christopher, S. A., Curtis, C. A., Schmidt, C. C., Eleuterio, D. P., Richardson, K. A., and Hoffman, J. P.: Global Monitoring and Forecasting of Biomass-Burning Smoke: Description of and Lessons From the Fire Locating and Modeling of Burning Emissions (FLAMBE) Program, IEEE J. Sel. Top. Appl. Earth Obs. Remote Sens., 2, 144-162, doi:10.1109/JSTARS.2009.2027443, 2009.

Rissler, J., Vestin, A., Swietlicki, E., Fisch, G., Zhou, J., Artaxo, P., and Andreae, M. O.: Size distribution and hygroscopic properties of aerosol particles from dry-season biomass burning in Amazonia, Atmos. Chem. Phys., 6, 471-491, doi:10.5194/acp6-471-2006, 2006.

Seinfeld, J. H. and Pandis, S. N.: Atmospheric chemistry and physics: from air pollution to climate change, Hoboken, N. J., Wiley, 1232 pp., 2006.
Spracklen, D. V., Carslaw, K. S., Pöschl, U., Rap, A., and Forster, P. M.: Global cloud condensation nuclei influenced by carbonaceous combustion aerosol, Atmos. Chem. Phys., 11, 9067-9087, doi:10.5194/acp-11-9067-2011, 2011.

Staudt, A. C., Jacob, D. J., Logan, J. A., and Sachse, G. W.: Continental sources, transoceanic transport, and interhemispheric exchange of carbon, J. Geophys. Res., 106, 3257132589, doi:10.1029/2001JD900078, 2001.

Taylor, J. W., Allan, J. D., Allen, G., Coe, H., Williams, P. I., Flynn, M. J., Le Breton, M., Muller, J. B. A., Percival, C. J., Oram, D., Forster, G., Lee, J. D., Rickard, A. R., Parrington, M., and Palmer, P. I.: Size-dependent wet removal of black carbon in Canadian biomass burning plumes, Atmos. Chem. Phys., 14, 13755-13771, doi:10.5194/acp-14-13755-2014, 2014.

van der Werf, G. R., Randerson, J. T., Giglio, L., Collatz, G. J., Mu, M., Kasibhatla, P. S., Morton, D. C., DeFries, R. S., Jin, Y., and van Leeuwen, T. T.: Global fire emissions and the contribution of deforestation, savanna, forest, agricultural, and peat fires (19972009), Atmos. Chem. Phys., 10, 11707-11735, doi:10.5194/acp10-11707-2010, 2010.

Wiedensohler, A.: An Approximation of the Bipolar ChargeDistribution for Particles in the Sub-Micron Size Range, J. Aerosol. Sci., 19, 387-389, 1988.

Wiedinmyer, C., Akagi, S. K., Yokelson, R. J., Emmons, L. K., AlSaadi, J. A., Orlando, J. J., and Soja, A. J.: The Fire INventory from NCAR (FINN): a high resolution global model to estimate the emissions from open burning, Geosci. Model Dev., 4, 625641, doi:10.5194/gmd-4-625-2011, 2011.

Yokelson, R. J., Crounse, J. D., DeCarlo, P. F., Karl, T., Urbanski, S., Atlas, E., Campos, T., Shinozuka, Y., Kapustin, V., Clarke, A. D., Weinheimer, A., Knapp, D. J., Montzka, D. D., Holloway, J., Weibring, P., Flocke, F., Zheng, W., Toohey, D., Wennberg, P. O., Wiedinmyer, C., Mauldin, L., Fried, A., Richter, D., Walega, J., Jimenez, J. L., Adachi, K., Buseck, P. R., Hall, S. R., and Shetter, R.: Emissions from biomass burning in the Yucatan, Atmos. Chem. Phys., 9, 5785-5812, doi:10.5194/acp-9-5785-2009, 2009 . 